\title{
Noise characterization of automotive auxiliary fan drives
}

\author{
S. Hofmann, S. Leitner(D, M. Mosshammer, A. Muetze
}

\begin{abstract}
The demand for low-noise auxiliary drives has been increasing in the automotive industry, as the entire noise level within the vehicle interior has been continuously decreasing over the recent years. In contrast to "larger" drives, the fractional horsepower (FHP) auxiliary drives used here are not subject to any standards. They are customized solutions and hardly anything is reported on their noise and vibration characteristics. Furthermore, their design is very much cost-driven, and noise performance is mostly treated in a retrofit approach within the final system. This article determines the noise and vibration characteristics of FHP auxiliary fan drive systems as typical for use within LED headlights for thermal management. It provides tools for further systematic analysis and eventual mitigation of potentially disturbing noise of such drives already at the development stage.
\end{abstract}

Keywords: automotive industry; auxiliary drives; fans; fractional horsepower drives; noise; NVH; performance evaluation

\section{Charakterisierung des Geräusch- und Vibrationsverhaltens von Hilfslüfterantriebe in Fahrzeugapplikationen.}

Aufgrund der kontinuierlichen Reduktion des Geräuschniveaus im Innenraum von Fahrzeugen hat die Nachfrage nach geräuscharmen Hilfsantrieben in der Automobilindustrie zugenommen. Im Gegensatz zu "größeren" Antrieben unterliegen die hier eingesetzten kleinen Hilfsantriebe keinen Normen, da sie typischerweise Spezialanfertigungen sind, über deren Geräusch- und Vibrationseigenschaften wenig bekannt ist. Darüber hinaus ist die Entwicklung solcher Antriebe sehr kostengetrieben, und das Geräuschverhalten wird meistens in einer Art Retrofit behandelt. Dieser Artikel beschreibt die Geräusch- und Vibrationscharakteristika kleiner Hilfs/üfterantriebssysteme, die typischerweise für das Temperaturmanagement in LED-Scheinwerfern eingesetzt werden. Er stellt Werkzeuge zur Verfügung, um diese Eigenschaften systematisch zu analysieren und parasitärer Geräuschentwicklung solcher Kleinantriebe bereits in der Entwicklungsphase zu begegnen.

Schlüsselwörter: Automobilindustrie; Geräuschentwicklung; Hilfsantriebe; Kleinantriebe; Lüfter; NVH; Performance-Evaluierung

Received January 21, 2020, accepted June 4, 2020, published online June 16, 2020

(c) The Author(s) 2020

\section{Introduction}

With increasing demands on comfort, safety, and performance, the number of auxiliary drives has been steadily increasing, with up to 100 of such drives used today in a mid-size passenger car [1, 2]. At the same time, the demand for overall noise level reduction has also become more rigorous, as both modern combustion engines and the increase of transportation electrification cause less noise to mask the noise of auxiliary drives [1] (see Fig. 1)

To meet the noise requirements within modern passenger cars, further understanding of the noise, vibration, and harshness (NVH) characteristics of auxiliary drives is of utmost importance. As a matter

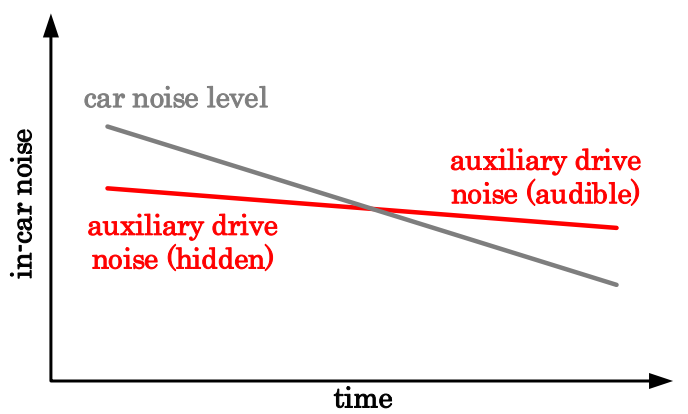

Fig. 1. In-car noise development over time [1] of fact, significant research has been carried out for integral horsepower drives. However, hardly anything systematic is known for fractional and sub-fractional horsepower drives. These small drives are not subject to any standards and typically developed as mass applications under tight time and financial constraints. The required noise performance of the system is often met in the form of a retrofit approach using, e.g., vibration absorbers which add to the cost.

Recently, the automotive sector initiated the development of proper noise standards, suggesting that the topic will gain increasing importance, calling for techniques to address the topic already at the design level of the individual drives and their components.

This article determines the noise and vibration characteristics of automotive auxiliary fan drive systems as typical for use within LED headlights for thermal managemenet. It identifies different techniques that are suitable for such analysis, as techniques established

Hofmann, Stefan, Christian Doppler Laboratory for Brushless Drives for Pump and Fan Applications, Electric Drives and Machines Institute, Graz University of Technology, Inffeldgasse 18/I, 8010 Graz, Austria (E-mail: stefanhofmann91@gmx.at); Leitner, Stefan, Christian Doppler Laboratory for Brushless Drives for Pump and Fan Applications, Electric Drives and Machines Institute, Graz University of Technology, Inffeldgasse 18/I, 8010 Graz, Austria (E-mail: s.leitner@tugraz.at); Mosshammer, Markus, Mechatronic Systems GmbH, Auf der Aue 11, 8551 Wies, Austria

(E-mail: markus.mosshammer@msg.at); Muetze, Annette, Christian Doppler Laboratory for Brushless Drives for Pump and Fan Applications, Electric Drives and Machines Institute, Graz University of Technology, Inffeldgasse 18/I, $8010 \mathrm{Graz}$, Austria (E-mail: muetze@tugraz.at) 


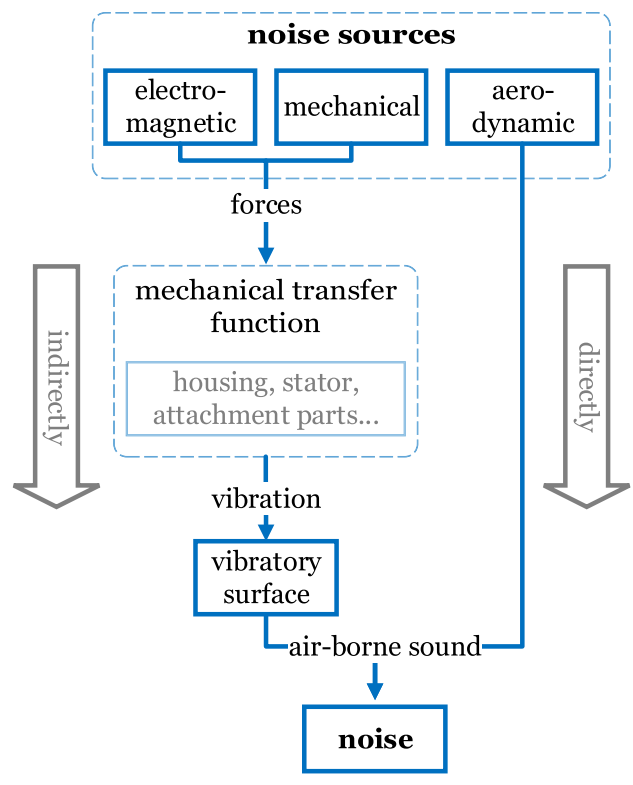

Fig. 2. Sources of noise in electric machines and drives [3]

in neighboring fields and/or with larger machines first need to be evaluated. Thereby, this article provides tools for further systematic analysis and eventual mitigation of potentially disturbing noise of such fractional horsepower drives already at the development stage.

In Sects. 2-3, this article reviews the noise generation of electric machines and drives, and overviews the performed fan noise investigations. The main part, consisting of Sects. 4-6, presents the results of a variety of experimental investigations. These include different air-borne and structure-borne sound measurements, and the investigation of the influence of different control techniques, rotational speed, and measuring positions. Finally, Sect. 7 concludes the findings of this article.

\section{Review of noise generation in electric machines and drives} With electric machines and drives, the following three sources of noise are distinguished between [3]: 1) mechanical, 2) electromagnetic, and 3) aerodynamic sources, which can either directly or indirectly lead to noise, as illustrated in Fig. 2. In general, the mechanical and electromagnetic sources generate forces, which act on different parts of the motor, such as the stator core or the stator housing, and other elements of the realized machine. Depending on the mechanical structure and thus its transfer functions, these forces can cause vibrations as shown in Fig. 2. Such oscillations are referred to as "structure-borne noise," which can subsequently result in so-called "air-borne noise" at a vibratory surface. Such noise is indirectly generated. On the other hand, aerodynamic sources typically generate noise directly, due to air pressure fluctuations and turbulence $[3,4]$. Both aerodynamic and mechanical noise are proportional to the rotational speed of the machine. In contrast, the electromagnetic noise strongly depends on the load condition. Thus, depending on the application, and notably its speed, one or another source may be more dominant.

The characteristics of the different noise sources of electrical machines and drives are detailed in the following:

(1) Mechanical noise sources mainly include mechanical unbalances of the rotating system, gear unit, bearings (slide or ball), friction, and manufacturing tolerances, which, in turn, can cause dynamic forces. The frequencies of mechanical noise are mainly related to the bearing parameters and to possibly occurring unbalances. Most dominant is typically the rotor unbalance, which manifests itself in a first order harmonic component equal to the rotational frequency [5].

(2) Electromagnetic noise is essentially caused by pulsating radial and tangential magnetic forces. The local radial and tangential force densites $f_{\mathrm{r}}$ and $f_{\mathrm{t}}$ can be calculated based on the Maxwell stress tensor:

$$
\begin{gathered}
f_{\mathrm{r}}=\frac{1}{2 \mu_{0}}\left(B_{\mathrm{r}}^{2}-B_{\mathrm{t}}^{2}\right) \\
f_{\mathrm{t}}=\frac{1}{\mu_{0}} B_{\mathrm{r}} B_{\mathrm{t}},
\end{gathered}
$$

where $\mu_{0}$ is the permeability of free space, and $B_{\mathrm{r}}$ and $B_{\mathrm{t}}$ are the radial and tangential components of the air-gap flux density, respectively. The radial magnetic pull is proportional to the square of the flux density. In a permanent magnet motor, the torque pulsations are a superposition of the cogging torque and torque ripples due to the operational principle of the machine. The latter include both torque ripples inherent to the machine due to non-ideal back-EMF waveforms and control-related torque ripples which are due to the switching and commutation. The cogging torque-which mainly occurs with permanent magnet machinescan be addressed by the motor design, the operational torque ripples as part of the control strategy of the drive. The frequencies of the electromagnetic noise are related to the torque and radial force harmonics.

(3) Aerodynamic sources directly generate air-borne noise in the form of air pressure fluctuations and turbulences. The noise spectrum of axial fan drives is typically dominated by only a few tonal noise components, the frequencies of which are related to the numbers of blades respectively struts of the fan and the rotational frequency. In contrast, the aerodynamic noise of radial fans is typically broadband (resulting from air flow through the air channel, ventilation drills, or cooling modules), including tonal blade passing noise (BPN) and interference noise components related to the housing [1]. The first dominant harmonic of the BPN is obtained by multiplication of the rotational speed by the number of blades; multiples thereof are typically also observed.

Subjective sound sensibility differs not only with the individuals, but also with the frequency, as the human ear is less sensitive to low than to high frequencies. While the terms "noise," "vibration," and "harshness" are often used jointly, as also mirrored in the established "NVH" acronym, they do refer to different frequency ranges [6]:

- Vibrations are defined as oscillations up to $20 \mathrm{~Hz}$, which are perceived exclusively as vibrations of the structure. (Road-excited vibrations being an example.)

- Harshness represents a transition zone, which is caused by oscillations in the range from $20 \mathrm{~Hz}$ to $50 \mathrm{~Hz}$. This type of oscillation is both audible and tactile. A typical example is the idle shaking of a combustion engine.

- Noise describes audible oscillations in the range from $50 \mathrm{~Hz}$ to $20 \mathrm{kHz}$. In automotive acoustics, these oscillations are rather located in the area of comfort than in driving dynamics.

Within these three fields which are frequently referred to at once, this article focuses on the Noise developed by the auxiliary drives. Typical sound pressure levels (SPL) are listed below for comparison with the experimentally determined SPLs [7]:

- low voice: $40 \mathrm{~dB}(\mathrm{~A})$

- normal conversation: $55 \mathrm{~dB}(\mathrm{~A})$ 
Table 1. Fan Systems Under Investigation

\begin{tabular}{llllll}
\hline Fansystem & $\begin{array}{l}\text { voltage } \\
\text { in V }\end{array}$ & $\begin{array}{l}\text { current } \\
\text { in A }\end{array}$ & $\begin{array}{l}\text { speed } \\
\text { in rpm }\end{array}$ & $\begin{array}{l}\text { number } \\
\text { of blades }\end{array}$ & type \\
\hline $\mathrm{E}$ & $8-16$ & 0.135 & 5000 & 64 & radial \\
$\mathrm{F}$ & $9-16$ & - & 5000 & 64 & radial \\
$\mathrm{G}$ & $9-16$ & - & 4000 & 64 & radial \\
$\mathrm{H}$ & $9-16$ & - & 6000 & 64 & radial \\
$\mathrm{I}$ & $8-16$ & - & 5000 & 0 & radial \\
$\mathrm{J}$ & 14 & 0.3 & 7000 & 37 & radial \\
$\mathrm{K}$ & 14 & 0.3 & 6850 & 37 & radial \\
$\mathrm{L}$ & 14 & 0.3 & 6650 & 37 & radial \\
$\mathrm{M}$ & 14 & - & - & - & radial \\
$\mathrm{N}$ & 14 & - & - & 37 & radial \\
\hline
\end{tabular}

- heavy city traffic: $92 \mathrm{~dB}(\mathrm{~A})$

- jet plane take-off: $150 \mathrm{~dB}(\mathrm{~A})$

\section{Overview of fan noise investigations}

The investigations presented in the following sections include 1) selected preliminary measurements (see Sect. 4), using inexpensive equipment for estimation, and 2) high quality measurements, which have been carried out in a low-reflection measurement chamber with a sophisticated microphone array (see Sect. 5) and professional acceleration and force sensors (see Sect. 6). The preliminary measurements have been performed using a readily available microphone positioned at different locations in the proximity of the respective fan drive suspended by elastomers, measuring the characteristics of the aerodynamic noise. (A sound-insulating box has been put over the entire setup and, additionally, an "empty measurement" has been carried out with the fan system deactivated to detect external influences.) The high quality measurements have been performed in approximation to the international standard ISO 13347-3 [8]. The influence of the measuring position, rotating speed, and control strategy on the SPL have been investigated.

Table 1 shows the different investigated radial fan drive systems. All of the investigated fan drives feature a single-phase outer-rotor brushless DC motor with four poles and a laminated iron core with an asymmetric air-gap to facilitate the starting.

Figures 3(a) and (b) illustrate the hardware of a typical automotive radial fan system used for Fansystems $\mathrm{E}-\mathrm{H}$. Fansystems $\mathrm{F}-\mathrm{H}$ have the same hardware as Fansystem E, but differ with respect to the control strategy. In contrast to Fansystem E, which is operated with frequency-hopping PWM control, Fansystems $\mathrm{F}-\mathrm{H}$ are implemented with an angle modulated switching strategy (AMSS), which needs only one switching cycle of the corresponding switch per electrical period, reducing the switching frequency and thus the electromagnetic emissions [9]. Fansystem I is identical to Fansystem E except for the rotor which has the blades removed, see Fig. 3(c), to minimize the aerodynamic noise. Fansystems J-N [see Fig. 11(b)] are also radial fans, similar to the fan shown in Figs. 3(a) and (b) but designed for a different operating point.

\section{Preliminary investigation of aerodynamic noise}

In order to extract the aerodynamic from the mechanical and electromagnetic noise components, Fansystem E has been modified by removing the fan blades of the rotor as illustrated in Fig. 3(c), which is denoted Fansystem I. As a result, the system load is reduced, as is the current (see Fig. 4). Yet, since the current shape hardly alters (it is still rectangular), the same dominant frequency components are to be expected and a comparison of Fansystems $E$ and $I$ is justified.

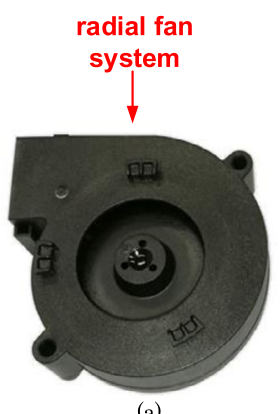

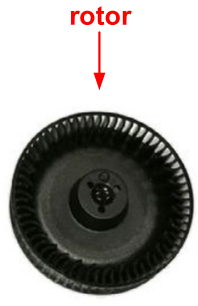

(b) modified rotor without blades

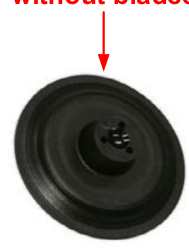

Fig. 3. Typical radial fan drive (Fansystems E-H) with its rotor and a modified rotor without blades (Fansystem I)
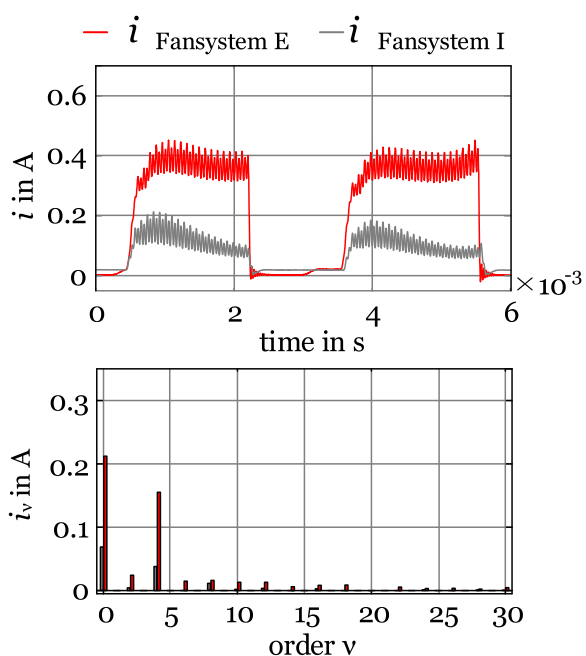

Fig. 4. Comparison of the measured supply currents (upper plot) and the corresponding order analysis (lower plot) of Fansystems E and I

These harmonics can trigger resonances of the system and lead to electromagnetic noise, which can be analyzed in subsequent investigations of the mechanical structure.

Figure 5 shows the order analysis of the noise spectra of Fansystems $\mathrm{E}$ ( 64 blades) and I (blades removed). The difference between Fansystems $E$ and I, especially in the range of $15<v<50$, can be attributed to the aerodynamic noise. As expected, when the rotor of Fansystem I is not balanced after the blades have been taken off, a distinct first order mechanical noise component is observed.

\section{Air-borne sound measurements in a low reflection chamber}

Air-borne sound measurements have also been carried out using microphones, according to the international standard ISO 13347-3 [8] as far as possible. A "type A" test setup (free inlet, free outlet) has been realized as illustrated in Fig. 6 . In addition, a separating element is used to distinguish the inflow from the outflow noise, in approximation to the hall room method (German standard DIN 45635 Part 38 [10])

For the near-field measurements either a radius of $0.5 \mathrm{~m}$ or $0.3 \mathrm{~m}$ is chosen, the latter in accordance with the preliminary measurements presented in Sect. 4. For the far-field measurements, an available microphone array has been used with a radius of $1.2 \mathrm{~m}$. Since the far- and near-field measurements yielded the same qualitative re- 


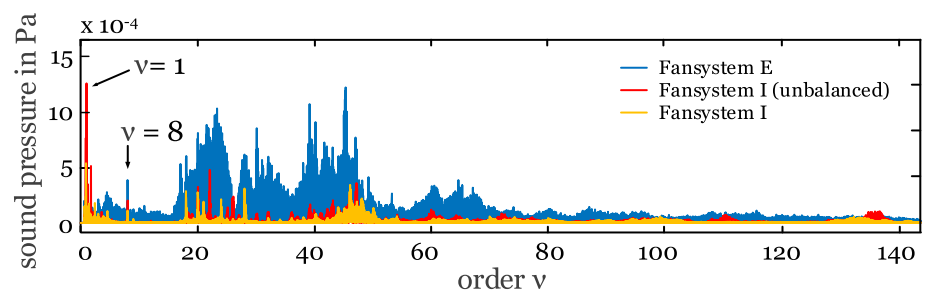

Fig. 5. Order analysis of the noise spectra of Fansystems E (64 blades) and I (no blades) at a distance of $0.3 \mathrm{~m}$

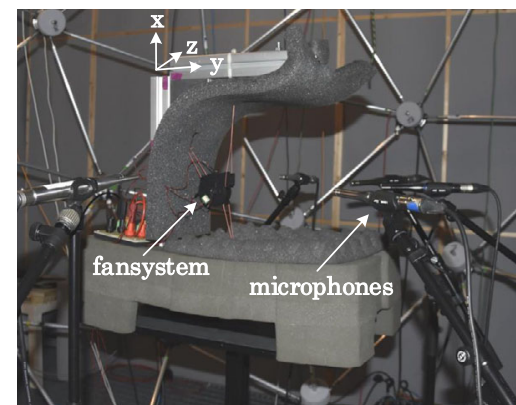

(a) measurement setup

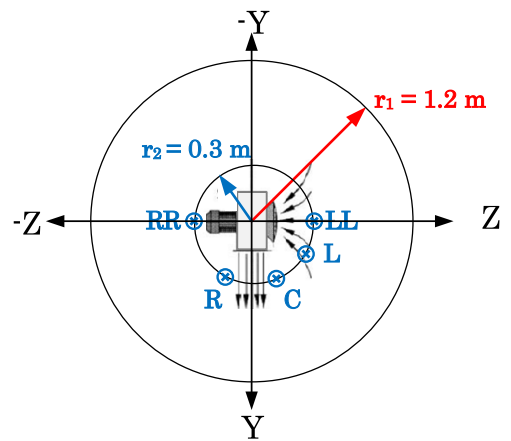

(b) bird's eye view

Fig. 6. Measurement setup for the air-borne noise and acceleration sensor measurements [see Fig. 11(a) for a detailed view of the fansystem]

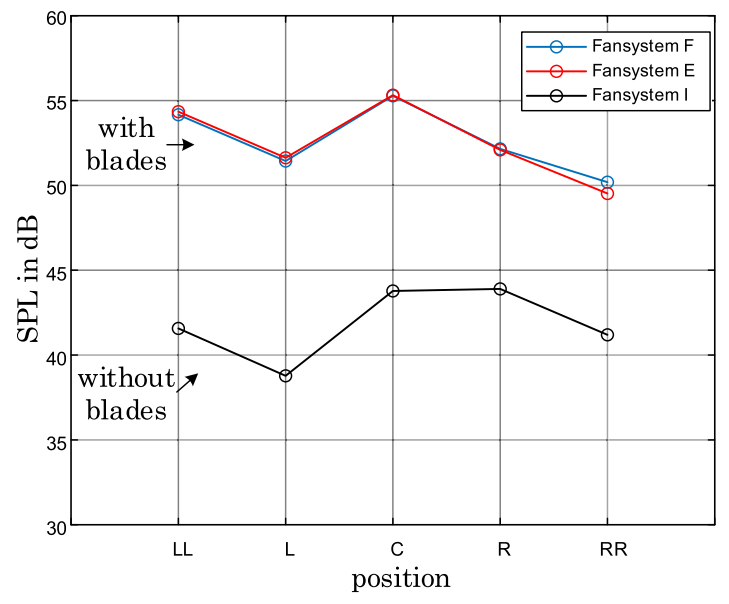

Fig. 7. Measured SPLS of Fansystems E, F, and I at different positions at $5000 \mathrm{rpm}$ and a distance of $0.3 \mathrm{~m}$

sults, where only the measured amplitudes differ due to the increased distance, only the near-field measurements are presented hereafter.

While proper noise standards for automotive auxiliary drives are still being developed, companies often have in-house standards with fairly strict requirements on the product. The Volkswagen standard VW 82469 [11] has been chosen for the standardized measurements. The measurement setup for air-borne sound measurements is based on the standard DIN EN 61672-1.

\subsection{SPL position dependence}

The SPL of a radial fan system often strongly depends on the measuring position, given the different directions of the inflow and outflow of air as well as the special shape of the housing. Figure $6(\mathrm{~b})$ shows the different measuring positions of the near-field measurements. It is expected that the inflow noise is dominant at position "LL" and the outflow noise is dominant at position "C."

Figure 7 shows the near-field SPLs of Fansystems E, F, and I measured at the positions according to Fig. $6(\mathrm{~b})$, when they are operated at $5000 \mathrm{rpm}$. Fansystems $\mathrm{E}$ and $\mathrm{F}$ exhibit very similar behavior even though they differ in the control strategy. This shows that for the studied fans, the control strategy has little influence on the air-borne noise. As expected, the SPLs of the Fansystem I, which has the blades removed, is much lower (about $10 \mathrm{~dB}$ ), due to the absence of aerodynamic noise. Hence, the aerodynamic noise is dominant for the studied Fansystems and rotational speed. The variation in SPLs with position can be explained by the distance to the respective noise sources and the different vibratory surfaces.

\subsection{SPL speed dependence}

The SPLs as a function of the rotational speed can be estimated with the help of an acoustic model law, e.g., according to Madison [12], according to which the SPL increases with the $\log _{10}$ of the rotational speed:

$$
\Delta L=10 \cdot \alpha \cdot \log _{10}\left(\frac{n_{2}}{n_{1}}\right),
$$

where $\Delta L$ is the change in SPL, $n_{1}$ is the initial speed, $n_{2}$ is the changed speed, and $\alpha$ is an empirical correction factor between 4 and 6 .

Figure 8 shows the measurement results of Fansystems $\mathrm{F}-\mathrm{H}$. All measured points show the expected logarithmic behavior of (3), except for measuring point " $R$," which may be explained by the fact that this speed does not excite the natural frequency of the housing in this direction to the same extent.

\subsection{Separation of in- and outflow noise}

In approximation to DIN 45635 [10], a separating element has been applied to the test setup shown in Fig. 6 in the $z x$-plane, which features a hole for the fan's outflow nozzle [10]. Two microphones are 


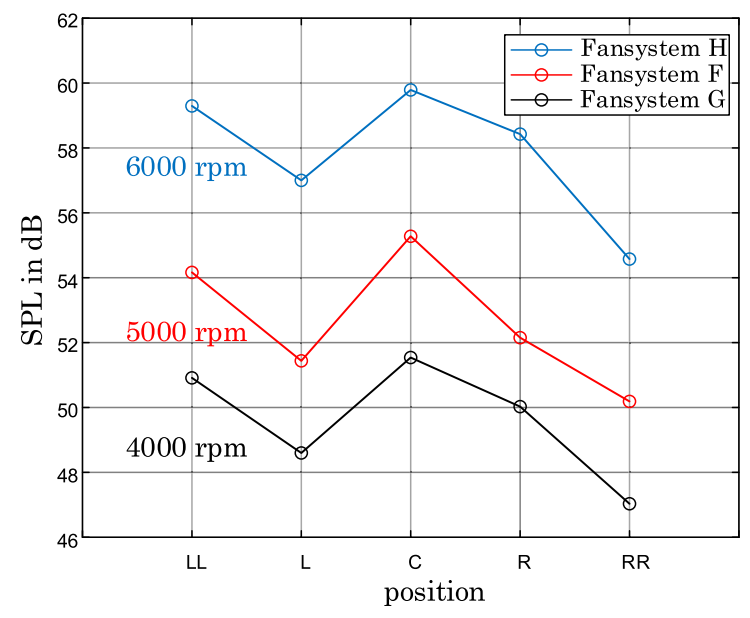

Fig. 8. Measured SPLs of Fansystems F-H operating at different rotational speed, measured at different positions at a distance of $0.3 \mathrm{~m}$

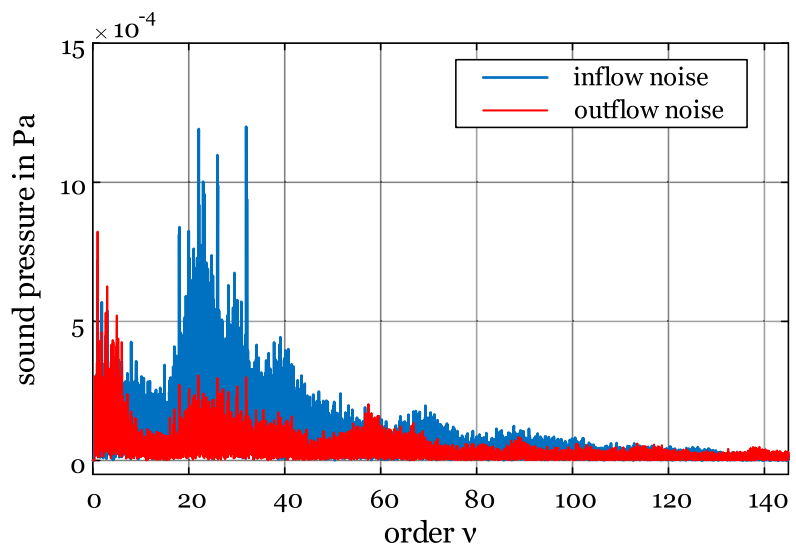

Fig. 9. Order analysis of the in- and outflow noise spectra of Fansystem $E$ at a distance of $0.3 \mathrm{~m}$

used, one positioned before and another behind the separating element, to determine the in- and outflow noise.

Figure 9 shows the measurement results of said microphone positions. While the inflow noise has distinct frequency components in the range of $10<v<50$, corresponding to a frequency range of 833 to $4166 \mathrm{~Hz}$, the outflow noise shows a clear attenuation of the amplitudes in the same range. This may be explained by the radial fan's inflow nozzle and rotor acting like a membrane. The same principal behavior was observed for Fansystems $\mathrm{F}-\mathrm{H}$ which differ in terms of control strategies and speeds but have the same housing

\subsection{Standardized measurements}

Depending on the specific area of application in a car, the one-third octave band analysis of the fan system must comply with different limit curves as follows [11]:

- Curve 1: passenger-operated auxiliary device which is activated when the combustion engine is on.

- Curve 2: passenger-operated auxiliary device which is activated when the combustion engine is off and those which operate automatically when the combustion engine is on.

- Curve 3: automatic auxiliary device when the combustion engine is off.

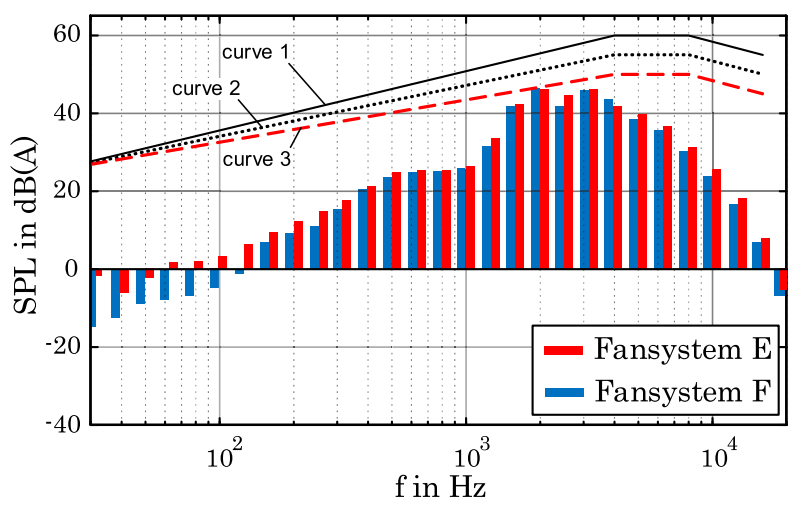

Fig. 10. One-third octave band analysis of the air-borne sound of Fansystems $E$ and $F$, including the limit curves

Furthermore, the determined total SPLs must not exceed 65, 60, and $55 \mathrm{~dB}(\mathrm{~A})$ for the three curves, respectively. Exemplarily, the measurement results of the inflow direction are reported on in the following. Figure 10 compares the A-weighted one-third octave band analyses of the air-borne sound of Fansystems $E$ and $F$; both measured in accordance with the industrial standard VW 82469 [11] but at a distance of 0.5 instead of $1 \mathrm{~m}$.

The results of Fansystems $E$ and $F$, which differ only in terms of control strategy, show very similar results. However, Fansystem $\mathrm{F}$ shows less attenuation below $400 \mathrm{~Hz}$, which can be explained by the used AMSS. (In contrast to a PWM strategy which splits the current into many blocks, AMSS supplies the electric machine with a single current block with a larger maximum value.) However, the total SPL of both fan systems is $52 \mathrm{~dB}(\mathrm{~A})$. The frequency range between 1000 and $5000 \mathrm{~Hz}$ is the most critical one as the one-third octave bands are in close proximity to the limits. Yet, given the reduced microphone distance $(0.5$ instead of $1 \mathrm{~m}$ ), both fansystems meet the requirements.

\section{Structure-borne sound measurements}

Two different structure-borne sound measurements were carried out using 1) three single-axis acceleration sensors mounted onto the housing of the tested fan systems suspended by elastomers [see Fig. 11(a)] and 2) two three-axis force sensors, where the fan systems are screwed onto a stainless steel cylinder [see Fig. 11(b)]. The latter arrangement is in accordance with the Volkswagen standard VW 82469 [11]. While the sensor weight is inherently of utmost importance for the acceleration measurements (the total sensor mass must remain below $10 \%$ of that of the fansystem [13]), it is not so much for the force measurements.

\subsection{Acceleration sensor measurements}

Figure 12 compares the one-third octave band analyses of the structure-borne sound of Fansystems $\mathrm{E}$ and $\mathrm{F}$ as determined by acceleration sensors shown in Fig. 11(a). To obtain the resulting effective force components, the obtained signals of the different directions have been added and then multiplied by the mass of the fansystem. Fansystems $\mathrm{E}$ and $\mathrm{F}$ show a similar characteristic. However, because of the increase in the current maxima, some peaks are slightly increased in Fansystem $\mathrm{F}$.

\subsection{Force sensor measurements}

Figure 13 compares the one-third octave band analyses of the structure-borne sound of Fansystems $\mathrm{M}$ and $\mathrm{N}$ as determined by 


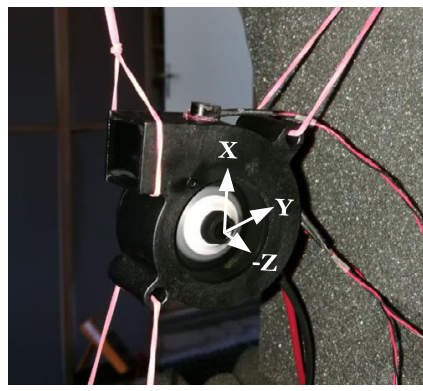

(a)

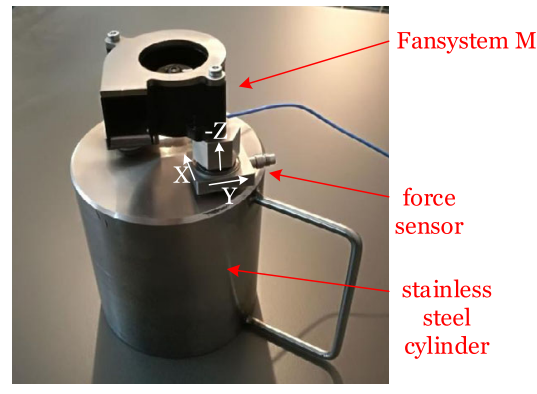

(b)

Fig. 11. Measurement setups: (a) acceleration measurement and (b) force measurement

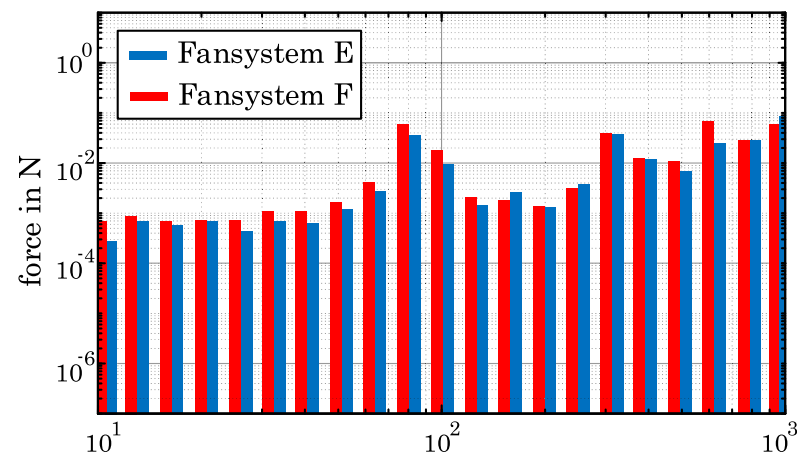

$\mathrm{f}$ in $\mathrm{Hz}$

Fig. 12. One-third octave band analysis of the structure-borne sound of Fansystems $E$ and $F$ as determined by acceleration sensors

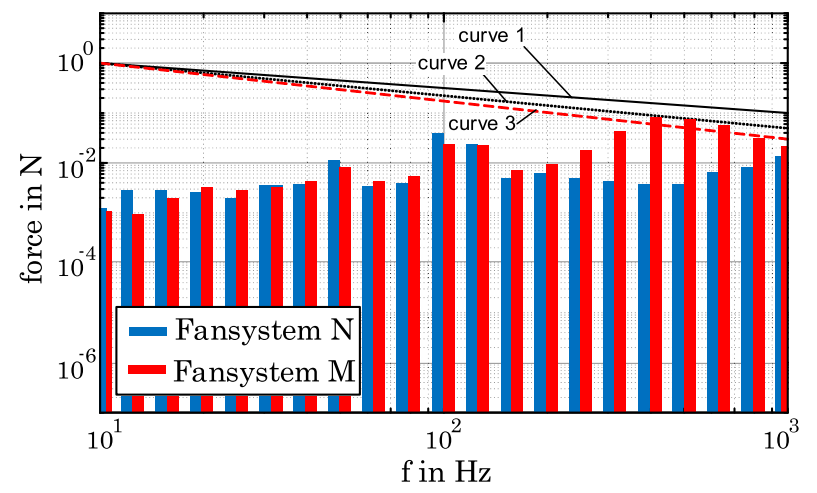

Fig. 13. One-third octave band analysis of the force measurement of Fansystems $N$ and $M$, including the limit curves

force sensors shown in Fig. 11(b). As characterized in the standard [11], all forces from all attachment points are added and represented as a one-third octave band spectrum. While Fansystem $\mathrm{M}$ exceeds the limit curve 3 in the range of 300 to $900 \mathrm{~Hz}$ (and can hence not be used as an auxiliary drive), Fansystem $\mathrm{N}$ remains below the limits in the whole range.

\section{Summary}

As the demand for low-noise auxiliary drives in the automotive industry has increased, further study on the different noise sources and the occurring frequencies as well as applicability of findings and methods developed for larger machines is required. It has been shown that the noise spectrum of radial fans is complex. By removing the fan blades, the aerodynamic noise has been significantly reduced and the mechanically and electromagnetically generated noise components have been allocated. Furthermore, the inflow and outflow noises of the studied radial fans have been separated successfully. In general, the occurring frequencies as well as SPLS strongly depend on the measuring position, the rotating speed, and the mechanical transfer function of the housing.

Further work may include modal analysis of the radial fansystem housing so as to determine the natural frequencies, use of a laser vibrometer so as to avoid the mass of the acceleration sensors influencing the results, measurements of the devices installed in the application because the structure-borne sound may trigger system resonances, and measurements at lower speeds so as to identify the influence of the cogging torque on the noise spectrum.

\section{Acknowledgements}

Open access funding provided by Graz University of Technology. The financial support by the Austrian Federal Ministry for Digital and Economic Affairs and the National Foundation for Research, Technology and Development is gratefully acknowledged. The authors also appreciate the excellent support of the Electronic Music and Acoustic Institute at the University of Music and Performing Arts, Graz, Austria, especially Ass. Prof. Franz Zotter, Dr. Mathias Frank, and DI Stefan Warum.

Publisher's Note Springer Nature remains neutral with regard to jurisdictional claims in published maps and institutional affiliations.

Open Access Dieser Artikel wird unter der Creative Commons Namensnennung 4.0 International Lizenz veröffentlicht, welche die Nutzung, Vervielfältigung, Bearbeitung, Verbreitung und Wiedergabe in jeglichem Medium und Format erlaubt, sofern Sie den/die ursprünglichen Autor(en) und die Quelle ordnungsgemäß nennen, einen Link zur Creative Commons Lizenz beifügen und angeben, ob Änderungen vorgenommen wurden. Die in diesem Artikel enthaltenen Bilder und sonstiges Drittmaterial unterliegen ebenfalls der genannten Creative Commons Lizenz, sofern sich aus der Abbildungslegende nichts anderes ergibt. Sofern das betreffende Material nicht unter der genannten Creative Commons Lizenz steht und die betreffende Handlung nicht nach gesetzlichen Vorschriften erlaubt ist, ist für die oben aufgeführten Weiterverwendungen des Materials die Einwilligung des jeweiligen Rechteinhabers einzuholen. Weitere Details zur Lizenz entnehmen Sie bitte der Lizenzinformation auf http://creativecommons.org/licenses/by/4.0/deed.de.

\section{References}

1. Zeller, P. (2009): Handbuch Fahrzeugakustik. 2nd ed. Wiesbaden: Vieweg+Teubner Verlag.

2. Hembach, H. Systematischer Vergleich von BLDC-Motorkonzepten mit Anwendung auf nass laufende Wasserpumpen kleiner Leistung. Ph.D. dissertation, Bundeswehr Universität München, Neubiberg, 28.11.2007. 
3. Knut, K. (2017): Vibrationen und Geräusche von elektrischen Antrieben. Essen: Haus der Technik.

4. Farschtschi, A. (2001): Elektromaschinen in Theorie und Praxis. 1st ed. Berlin: VDE Verlag.

5. Timár, P. L., Fazekas, A., Kiss, J., Miklós, A., Yang, S. J. (1989): Noise and vibration of electrical machines. Amsterdam: Elsevier.

6. Tschoeke, H. (2015): Die Elektrifizierung des Antriebsstrangs - Basiswissen. Wiesbaden, Deutschland: Springer.

7. Gieras, J. F., Wang, C., Lai, J. C. (2006): Noise of polyphase electric motors. 6000 broken sound parkway NW. In Suite (Vol. 300). Boca Raton: Taylor \& Francis Group, LLC.

8. Industrial fans - determination of fan sound power levels under standardized laboratory conditions - Part 3. International Standard ISO 13347-3, 2004

\section{Authors}

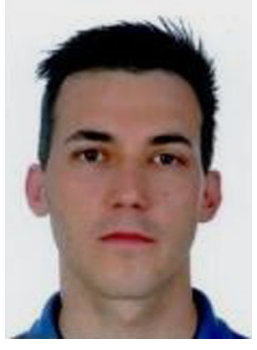

\section{Stefan Hofmann}

received the B.Sc. and Dipl.-Ing. degrees in electrical engineering from Graz University of Technology, Graz, Austria, in 2017 and 2019, respectively. He wrote his Master's Thesis within the framework of the Christian Doppler Laboratory for Brushless Drives for Pump and Fan Applications, at the Electric Drives and Machines Institute at Graz University of Technology, Graz, Austria. His research interests include the noise, vibration, and harshness (NVH) behavior of fractional hp electric drives.

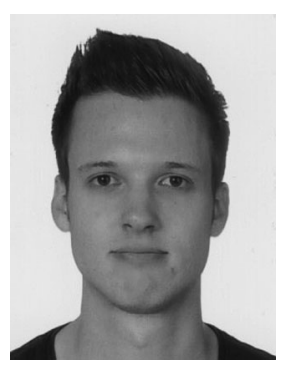

\section{Stefan Leitner}

received the B.Sc. degree and the Dipl.-Ing. degree in electrical engineering from Graz University of Technology, Graz, Austria, in 2014 and 2016, respectively. He is currently pursuing his Ph.D. degree in electrical engineering at the Electric Drives and Machines Institute at Graz University of Technology, Graz, Austria. He spent an academic year at the University of Tennessee, Knoxville, USA, in 2014-15, via the International Student Exchange Program (ISEP). He was a visiting scholar at Washington State University, Pullman, WA, USA, and a recipient of the Marshall Plan Scholarship in 2016. He was awarded Oesterreichs Energie-Preis 2017 for his Master's Thesis. His research interests include the design of fractional hp drives, finite element analysis, and microgrids. Mr. Leitner is a member of the Christian Doppler Laboratory for Brushless Drives for Pump and Fan Applications.
9. Krall, F., Gruebler, H., Muetze, A. (2019): Angle modulated switching strategy for fractional horsepower BLDC motors for improved electromagnetic compatibility. In 2019 21th European conference on power electronics and applications (EPE'19 ECCE Europe) (pp. P.1-P.7).

10. Geräuschmessung an Maschinen, Luftschallemission, Hülfflächen-, Hallraum-, und Kanal- Verfahren - Ventilatoren. Deutsche Norm DIN 45635 Teil 38, 1986

11. Bielert, F. (2014): Zusatzaggregate - Akustische Anforderungen, Volkswagen Konzernnorm. VW 82469

12. Carolus, T. (2013): Ventilatoren - Aerodynamischer Entwurf, Schallvorhersage, Konstruktion. 3rd ed. Siegen, Deutschland: Springer.

13. Acoustics determination of airborne sound power levels emitted by machinery using vibration measurement. ÖNORM, ISO TS 7849, 2017

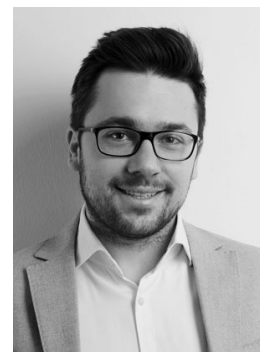

\section{Markus Mosshammer}

received the Dipl.-Ing. and Dr.techn. degrees in mechanical engineering from Graz University of Technology, Graz, Austria, in 2011 and 2018, respectively. His research interests include numerical and experimental analysis with focus on pumps, fans, and turbine applications. Dr. Mosshammer is currently with Mechatronic Systems GmbH, Wies, Austria, working as a research and development expert.

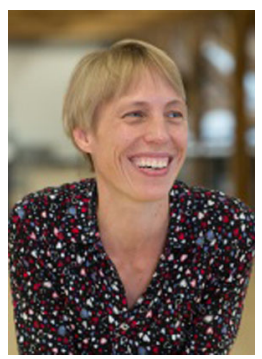

\section{Annette Muetze}

received the Dipl.-Ing. and Ph.D. degrees in electrical engineering and information technology from the Darmstadt University of Technology, Darmstadt, Germany, and the degree in general engineering from Ecole Centrale de Lyon, Ecully, France, both in 1999, and the Dr.Ing. degree in electrical engineering from the Darmstadt University of Technology, in 2004. She is a Full Professor with the Graz University of Technology, Graz, Austria, where she heads the Electric Drives and Machines Institute and the Christian Doppler Laboratory for Brushless Drives for Pump and Fan Applications. Prior to joining the Graz University of Technology, she was an Assistant Professor at the University of Wisconsin-Madison, Madison, WI, USA, and an Associate Professor at the University of Warwick, Conventry, U.K. Dr. Muetze was the recipient of the NSF CAREER Award in 2004 and a recipient of the 6th Nagamori Award in 2020. 